\title{
A UNICIDADE ORGÂNICA DA REPRESENTAÇÃO JUDICIAL E DA CONSULTORIA JURÍDICA DO ESTADO DE MINAS GERAIS ${ }^{1}$
}

$$
2^{a} e \text { dição } o^{2}
$$

\section{MaRCo Túlio DE CARvalHo Rocha*}

1. Advocacia Pública e Advocacia de Estado - 2. Antecedentes Normativos da Advocacia de Estado na União e no Estado de Minas Gerais 3. O Art. 132 da Constituição Federal - 4. Prerrogativas Constitucionais Implícitas dos Procuradores dos Estados: o Controle da Legalidade e a Organicidade Funcional - 5. Prerrogativas Constitucionais Implícitas dos Procuradores dos Estados: o Controle da Legalidade e a Independência Funcional - 6. A Inconstitucionalidade das Normas Infringentes ao Princípio da Unicidade no Estado de Minas Gerais - 7. Os Argumentos Contrários à Unicidade: a Simetria dos Textos Constitucionais - 8. Os Argumentos Contrários à Unicidade: a Natureza Jurídica do Disposto no Art. 132 da Constituição Federal; a Supremacia dos Interesses Defendidos pelo Governador; a Constitucionalidade das Procuradorias das Assembléias Legislativas; a Conveniência Político-Administrativa - 9. O Art. 132 da Constituição Federal na Interpretação do Supremo Tribunal Federal - 10. Conclusão.

\section{Advocacia Pública e Advocacia de Estado}

A representação judicial e a consultoria jurídica são as atividades típicas e

1 Tese aprovada por unanimidade no XXIV Congresso Nacional de Procuradores de Estado, realizado de 30 de agosto a 3 de setembro de 1998 em Campos do Jordão-SP.

2 Ao texto original acrescentamos: no tópico 8, a análise da constitucionalidade das procuradorias das Assembléias Legislativas; no tópico 6, o argumento de que a exceção prevista no art. 69 dos Atos das Disposições Constitucionais Provisórias (ADCT), da Constituição Federal, confirma o princípio da unicidade.

* Procurador do Estado de Minas Gerais. Mestrando da Faculdade de Direito da UFMG.

R. Dir. Adm.,

Rio de Janeiro, 223: 169-197,

jan./mar. 2001 
privativas da advocacia que a qualificam conforme sejam prestadas em prol de entes públicos ou privados. De fato, apesar de terem o mesmo estatuto normativo a reger suas características essenciais, distingue-se a advocacia pública da advocacia privada em razão da natureza dos interesses aconselhados ou patrocinados: diferentemente do interesse privado, no interesse público prevalece não a vontade do agente que o manifesta, mas o interesse abstrato da coletividade, tutelado pelas diretrizes constitucionais e legais ${ }^{3}$.

Outro traço que distingue as duas espécies de advocacia são os requisitos para o seu exercício: além do preenchimento dos requisitos necessários ao exercício da advocacia privada (cf. Lei $\mathrm{n}^{\circ} 8.906 / 94$, Estatuto da OAB, art. $8^{\circ}$ ), o exercício da advocacia pública exige que o agente seja aprovado em concurso público de provas e títulos e que seja investido em cargo organizado em carreira.

Ao tratarmos, portanto, da representação judicial e da consultoria jurídica do Estado de Minas Gerais, estamos navegando nas águas da advocacia pública. Essa expressão é empregada numa acepção muito ampla pelo administrativista DIOGO DE FIGUEIREDO MOREIRA NETO de modo a abranger não só as funções exercidas por advogados, mas também as funções exercidas pelos membros do Ministério Público ${ }^{4}$. Apesar de discutível o uso que faz do termo "advocacia pública", o administrativista tem no seu ativo o realce das características que fazem do Ministério Público, da Advocacia de Estado e da Defensoria Pública funções essenciais à Justiça, em inteira consonância com a unidade orgânica que ostentaram no passado e que se tornou superada somente em razão da inevitável especialização do trabalho.

$\mathrm{O}$ autor citado diz que a advocacia pública destina-se à defesa dos interesses públicos, individuais, coletivos e difusos que a ordem jurídica lhe cometer, sendo seus órgãos singulares os advogados públicos e seus órgãos coletivos as procuradorias, entre as quais incluem-se as por ele denominadas "procuraturas constitucionais" 5 .

As "procuraturas constitucionais" são os órgãos cujos estatutos básicos encontram-se disciplinados nos arts. 127, 129, 131, 132, 133 e 134 da Constituição Federal, voltadas cada uma delas a conjuntos de interesses característicos.

3 SESTA, Mário Bernardo. Advocacia de Estado: Posiçāo Institucional. Rev. de Inf. Legislativa, n ${ }^{\circ} 117$, jan./mar. 1993. Brasília. p. 187-202, espec. 191.

4 MOREIRA NETO, Diogo de F. As Funçōes Essenciais à Justiça e as Procuraturas Constitucionais. Revista da Procuradoria Geral do Estado de São Paulo, dez. 1991, p. 11-43).

5 O termo "procuratura", sinônimo de "procuradoria" foi eleito por MOREIRA NETO sob a justificativa de que "a expressão procuradoria pode ser reservada para o gênero, de vez que abrangerá outros órgãos públicos ou privados, de prestação de serviços jurídicos. A espécie aqui tratada, da advocacia pública de radical constitucional, fica, portanto, melhor identificada com designação própria, assinalando, ainda, com a parcial paronímia da palavra 'procuratura' com 'magistratura', uma aproximação e uma assemelhação que o próprio legislador constitucional quis destacar, como se exporá adiante". (Cf. MOREIRA NETO, Diogo de F. As Funções Essenciais à Justiça e as Procuraturas Constitucionais. Revista da Procuradoria Geral do Estado de São Paulo, dez. 1991, p. 11-43, espec. 40). 
O primeiro conjunto de interesses envolve o que o autor denomina de "advocacia da sociedade", estando a cargo do Ministério Público. O segundo conjunto é o dos interesses públicos estabelecidos em lei e cometidos ao Estado em seus desdobramentos políticos (União, Estados e Distrito Federal); a função correspondente a esse conjunto é a "Advocacia de Estado" e as procuraturas que as tem a seu cargo são a Advocacia-Geral da União (art. 131, CF) e as Procuradorias dos Estados e do Distrito Federal (art. 132, CF). O terceiro conjunto de interesses é caracterizado pela insuficiência de recursos daqueles que devam ou queiram defendê-los: são os interesses dos necessitados, e a "procuratura" que lhe corresponde é a Defensoria Pública (art. 134, CF).

Por fim, ressalta MOREIRA NETO, às três procuraturas constitucionais compete "a função de controle institucional de provedoria, sendo, portanto, públicas não só quanto à finalidade mas também quanto aos agentes, pois são exercidas por agentes públicos (...)" 6 .

Outra característica comum às "procuraturas constitucionais" é a essencialidade de suas funções: são órgãos de Estado, isto é, não são meros órgãos administrativos de caráter contingente. Sua existência advém do quadro institucional adotado pela Constituição Federal de 1988, sendo, por isso, de existência necessária.

Não se pode olvidar que a Constituição Federal não esgota o quadro da advocacia pública e, notadamente, das procuradorias públicas, incluindo-se indubitavelmente nesses conceitos as procuradorias dos municípios (típica Advocacia de Estado), e as procuradorias dos entes da administração indireta: de autarquias, fundações públicas, empresas públicas etc.

Feita a distinção entre a advocacia pública e a advocacia privada, verificado que, no campo da advocacia pública, distinguem-se o Ministério Público e a Defensoria Pública, da Advocacia de Estado - se admite-se a expressão na acepção mais ampla, já analisada - cumpre verificar ainda se esta última expressão designa a advocacia de todos os entes estatais, sejam os da administração direta, sejam os da administração indireta.

BERNARDO SESTA sinaliza a solução para a questão sob o mesmo critério do interesse que nos guiou até aqui. Diz que o objeto da Advocacia de Estado é a tutela do interesse público, do interesse do Estado, compreendido esse, em razão da estrutura federativa, como "pessoa administrativa necessária". Afirma que o interesse do Estado é a "realização da Justiça" e destaca, por isso, a felicidade com que se houve o constituinte ao designar a Advocacia de Estado como função essencial à Justiça ${ }^{7}$.

6 MOREIRA NETO, Diogo de F. Op. cit. p. 24-25.

7 O termo "Justiça" é aqui empregado numa acepção que não se confunde com o objeto da atividade jurisdicional, mas no sentido que abraça toda a atividade estatal e que diz respeito diretamente aos fins do Estado como um todo, como explica SÉRGIO DE ANDRÉA FERREIRA: "o que se busca com a atuação dessas instituições é a realização da justiça, tornando esse termo não apenas no sentido de justiça de estrita legalidade; de justiça jurisdicional mas da justiça abrangente da eqüidade, $d a$ legitimidade, $d a$ moralidade. (...) Não nos deixemos impressionar com 
Conclui: “(...) a estrutura estatal, como um todo, cujo interesse é necessariamente sincrônico com o respectivo núcleo organizativo-gravitacional, inclui não só o interesse da estrutura do chamado 'Poder Executivo', ao qual compete a presentação do Estado, como ainda dos demais 'Poderes'; abrange o interesse das autarquias, das empresas públicas, das sociedades de economia mista e das fundações sob controle estatal. Poder-se-ia até entender, sem nenhuma demasia, que a abrangência conceitual do interesse estatal transcende o complexo estrutural pertinente ou diretamente subordinado ao Estado, para incluir também o das instituições privadas que, por delegação, permissão, concessão ou contrato prestam serviços públicos, ao menos naquilo que pertina ao universo do publicum" ${ }^{8}$.

A fortiori: se a Advocacia de Estado representa o interesse público estatal de realização da Justiça; se esse interesse espraia-se pela administração direta e indireta, e até além dela, alcançando as instituições privadas; então, há de ser igualmente abrangente o campo da Advocacia de Estado.

De outra parte, se a Advocacia de Estado é a que se realiza face às "pessoas administrativas necessárias" - a União, os Estados, o Distrito Federal e os Municípios, art. $1^{\circ}, \mathrm{CF}$ - nos assuntos que se contêm dentro de seus objetivos institucionais, sobre os quais não recai diretamente o interesse público estatal, as pessoas jurídicas da administração indireta são assessoradas e representadas judicialmente por advogados de empresa, autárquicos, fundacionais etc. Os entes da administração indireta devem ter, por isso, representação judicial e consultoria jurídica mista (cf. infra, $\left.\mathrm{n}^{\circ} 4\right)$.

\section{Antecedentes Normativos da Advocacia de Estado na União e no Estado de Minas Gerais}

A distinção das funções essenciais à Justiça foi obra da Constituição Federal de 1988. Dentre inúmeras inovações, ela contemplou a disciplina básica da representação judicial e da ccnsultoria jurídica dos Estados-membros e do Distrito Federal no artigo 132, cujo texto, alterado pela Emenda Constitucional $n^{\circ} 19$, promulgada

a ênfase que alguns dispositivos desse Capítulo IV atribuem ao relacionamento da atividade dessas instituições com a função jurisdicional (cf. arts. 127, 131, 132 e 134). É claro que a Justiça, mesmo a abrangente, a compreensiva, se faz, em grande parte, mediante a provocação e a prestação da função jurisdicional. Mas não só através desse meio. E tanto é assim, que a atuação dessas instituições se desenvolve, também, em face de outros Poderes" (in. Comentários à Constituição. V. 3. Rio de Janeiro: Freitas Bastos. p. 12.). No mesmo sentido, BERNARDO SESTA: " $O$ interesse do Estado manifestado, quer através de seus órgãos máximos, expressivos da soberania, quer através de todo complexo de órgãos de sua administração direta, quer, inclusive, através da vasta gama dos órgãos da chamada administração descentralizada, mesmo aqueles organizados com base no formulário peculiar ao direito privado, é, nada mais e nada menos, do que a realização da Justiça, visualizada de acordo com as concepçōes filosóficas e políticas, explícita ou implicitamente adotadas pela ordem institucional correspondente". (Op. cit., p. 193).

8 SESTA, Mário B. Op. cit. P. 192-193. 
em 4 de junho de 1998, é o seguinte: "Os Procuradores dos Estados e do Distrito Federal, organizados em carreira, na qual o ingresso dependerá de concurso público de provas e títulos, com a participação da Ordem dos Advogados do Brasil em todas as suas fases, exercerão a representação judiciai e a consultoria jurídica das respectivas unidades federadas.

Parágrafo único. Aos procuradores referidos neste artigo é assegurada estabilidade após três anos de efetivo exercício, mediante avaliação de desempenho perante os órgãos próprios, após relatório circunstanciado das corregedorias".

A regulamentação da Advocacia de Estado - dos Estados-membros, do Distrito Federal, e da União (arts. 131 e 132, CF) - pela Constituição, é uma importante etapa do longo percurso da história da democratização das instituições, da transparência das relações de poder, e, nas palavras de MOREIRA NETO, da submissão do Estado "ao direito, à vontade da sociedade e à moral". 9 Do mesmo teor é a lição de BERNARDO SESTA: "a evolução histórica da Advocacia do Estado, a partir dos les gens du roi até hoje, nada mais é do que a evolução das instituiçōes estatais, do absolutismo ao Estado Democrático social contemporâneo" ${ }^{10,11}$.

Por essa nobre filiação aos mais lídimos anseios humanos e às mais altas elaborações intelectuais e éticas de nossa história, é que se entende que a relevância institucional da Advocacia de Estado não decorre de sua constitucionalização. Ao contrário, a instituição da Advocacia de Estado pela Constituição Federal, sua inclusão entre as "funções essenciais à Justiça" e o regime jurídico especial que lhe foi atribuído, "não são mais do que mera conseqüencia das premissas definidoras do Estado de Direito, adotadas pelo constituinte brasileiro, que deu particular relevo ao caráter participativo do modelo democrático escolhido e, coerentemente, buscou assegurar os melhores instrumentos de preservação do princípio da legalidade administrativa". ${ }^{12}$

9 MOREIRA NETO, Diogo de F. As Funções Essenciais à Justiça e as Procuraturas Constitucionais. Revista da Procuradoria Geral do Estado de São Paulo, dez. 1991, p. 11-43, espec. 12.

10 SESTA, Mário Bernardo. Advocacia de Estado: Posição Institucional. Rev. de Inf. Legislativa, n 117, jan./mar. 1993. Brasília. P. 187-202, espec. 190.

11 O mesmo autor explica essa assertiva em outro texto: "Inicialmente, os interesses do Erário ou do Estado eram indistintos dos do próprio monarca ou, quando distintos à base de teorizações fundadas no direito privado ou em disquisiçōes teológicas, mesmo assim jaziam à sua mercê. Aos poucos, na medida em que o Povo conquistava o Estado, construindo sua liberdade sobre as parcelas de poder que subtraía ao déspota, ganhava identidade, contraposto ao do Rei, o interesse popular, progressivamente expresso no abstrato coletivo designado como 'interesse público' ou interesse do Estado, de que o monarca, e seus sucessores no desdobrar da História, passaram a ser gestores em lugar de senhores. Não mais à sua mercê estava esse conjunto cada vez mais vasto de interesses, revestido que passava a ser da objetividade ou impessoalidade que o rendia indisponivel, insuscetivel de ser administrado mediante atos de senhoria, sujeito a fins colimados em lei. delineada, assim a par da gestão privada, a gestão pública ou administração em sentido técnico-jurídico, que passou a ser o modo próprio do trato da coisa pública". (in, Advocacia de Estado, Discurso Proferido na Escola Superior de Advocacia do Rio Grande do Sul. Rev. Advogado, $\mathrm{n}^{\circ} 18$, maio/dez/92).

12 SESTA, Mário B. Advocacia de Estado: Posição Institucional. Op. cit., p. 199. 
No Brasil, antes da Constituição de 1988 os serviços da Advocacia de Estado tinham sido cometidos, em épocas distintas, aos membros do Ministério Público, a advogados contratados e a advogados públicos organizados em carreiras instituídas pela lei ordinária ${ }^{13}$.

No nível da União, a primeira menção constitucional à advocacia estatal é encontrada no art. 48 da Constituição Imperial que atribuiu ao Procurador da Coroa e Soberania Nacional a competência para a acusação no Juízo dos crimes. O Decreto $n^{\circ} 5.618$, de 2 de maio de 1874 , conferiu-lhe a competência também para o exercício da Advocacia de Estado. Com o advento da República, o representante passou a denominar-se Procurador-Geral da República, com a competência conferida pela lei (art. 58, $\S 2^{\circ}$ ). A Lei ${ }^{\circ} 221$, de 20 de novembro de 1894 , regulou a competência do Ministério Público Federal, outorgando-lhe o exercício da Advocacia de Estado (art. 28) ao lado de suas atribuições típicas. A Constituição de 1934 não inovou a matéria (arts. 95 a 98). A de 1937 determinou em um único artigo que o Procurador-Geral da República, chefe do Ministério Público Federal, seria escolhido pelo Presidente da República. A Constituição de 1946 atribuiu expressamente ao Ministério Público a representação judicial da União, permitindo inclusive que fosse feita pelo Ministério Público local, nas comarcas do interior (art. 126, parágrafo único), dispositivo regulamentado pela Lei Federal n 1.341 , de 30 de janeiro de 1951 (Lei Orgânica do Ministério Público da União - arts. 30, I; 37 e 38, I). A mesma regulamentação deu à matéria o texto constitucional de 1967 (art. 138, §2 $2^{\circ}$ ) e o texto emendado de 1969 (art. 95, \& $2^{\circ}$ ).

No Estado de Minas Gerais, a Constituição Estadual de 1891 limitou-se a determinar que na Relação (Tribunal) haveria um Procurador Geral (Chefe do Ministério Público) designado pelo Governo. A Lei n ${ }^{\circ} 375$, de 19 de setembro de 1903 , conferiu ao Sub-Procurador a competência para representar o Estado em juízo e para exercer as atividades de consultoria jurídica junto às Secretarias de Estado (art. 225). A Lei 912/25 modificou a competência do Ministério Público. Mediante o Decreto $n^{\circ} 76$, de 3 de junho de 1935, o Estado atribuiu ao Ministério Público competência para promover a cobrança da dívida ativa da Fazenda Estadual. Nove dias após, em 12 de junho de 1935, o Decreto Estadual $n^{\circ} 95$ criou o Serviço Contencioso e de Consultas Jurídicas do Estado, para representar o Estado judicialmente e prestar a consultoria jurídica junto ao Governador do Estado e das Secretarias de Estado. Dispunha o referido decreto que o Serviço seria diretamente subordinado ao Governador do Estado, sob a direção do Advogado Geral. No art. 12, determinou-se a extinção da Procuradoria Fiscal e da Consultoria Jurídica das Secretarias existentes à época. A Constituição Estadual de 30 de julho de 1935 inovou ao dedicar um de seus títulos ao Ministério Público, deixando à lei, contudo, a regulamentação de sua competência. A de 1945 não trouxe qualquer inovação, tratando da matéria em seu

13 Além da expressa atribuição aos Procuradores de Estado da competência para o exercício da representação judicial e da consultoria jurídica dos Estados-membros, a Constituição Federal, também expressamente, excluiu aquelas funções da competência do Ministério Público por meio das vedaçōes contidas no art. $128, \S 5^{\circ}$, inciso II, alíneas "b" e "c". e no inciso IX no art. 129. 
art. 66. A de 1947. idem. Em 6 de setembro de 1955, a Lei Estadual $\mathrm{n}^{\circ} 1.291$ reorganizou o Departamento Jurídico do Estado determinando que a cobrança da dívida ativa estadual fosse feita por ele em cooperação com a Secretaria das Finanças que tinha sob a sua orientação e para a realização do serviço, Promotores de Justiça e advogados contratados. Eram ainda funções do Departamento Jurídico a consultoria jurídica aos órgãos da administração direta e a assistência judiciária na justiça gratuita. Em 13 de fevereiro de 1960, o Decreto $n^{\circ} 5.757$ aprovou o regulamento do Departamento Jurídico do Estado com funções de advocacia, consultoria, assistência jurídica a Secretarias de Estado e outros órgãos da administração e assistência judiciária. De acordo com o art. $4^{\circ}$ do mencionado decreto, os serviços de representação jurídica do Estado estariam afetos ao Advogado-Geral, aos Advogados Consultores, aos Assistentes Jurídicos, aos Promotores de Justiça ou a advogados que fossem designados ad hoc. O Decreto $\mathrm{n}^{\circ} 6.386$, de 18 de novembro de 1961, aprovou outro regulamento para o Departamento Jurídico do Estado, sem, contudo, trazer grandes inovações em relação ao anterior. A Constituição Mineira de 1967 estabeleceu a estrutura básica do Ministério Público (arts. 152 a 162), autorizando-lhe o desempenho de representação judicial de entidade de direito público e a "assistência ou patrocínio oficial por encargo de lei ou delegação por esta autorizada". A grande alteração que sobreveio à representação judicial do Estado, se deu em razão da Lei $n^{\circ} 5.047$, de 27 de novembro de 1968, que criou a Procuradoria Fiscal do Estado como órgão subordinado à Secretaria da Fazenda com competência para representar judicialmente o Estado nas causas que envolvessem interesse de natureza tributária. A regulamentação da organização e do funcionamento da Procuradoria Fiscal fez-se pelo Decreto $\mathrm{n}^{\circ} 11.556$, de 30 de dezembro de 1968. A Emenda Constitucional $n^{\circ} 1$, de 1970 , que alterou a redação da Constituição de 1967 , repetiu no art. 91 a autorização que a Constituição do Estado conferira ao Ministério Público. Em 10 de setembro de 1973, foi publicado o Decreto $n^{\circ} 15.717$ que reorganizou o Departamento Jurídico do Estado, dele não resultando qualquer alteração relevante no rol de suas atribuições e na composição de seu quadro. O mesmo se diga sobre a Lei $\mathrm{n}^{\circ} 7.130$, de 3 de novembro de 1977. O Decreto $\mathrm{n}^{\circ} 19.058$, de 17 de janeiro de 1978, criou as Procuradorias Regionais da Fazenda, em número de 12 (art. $4^{\circ}$, $\S$ $2^{\circ}$ ). A Lei 7.900 , de 23 de dezembro de 1980, criou a Procuradoria Geral do Estado de Minas Gerais em substituição ao Departamento Jurídico; autorizou o Poder Executivo a criar o Quadro dos Defensores Públicos e também o Quadro dos Procuradores Fiscais (arts. 59 e 60). O Decreto $n^{\circ} 21.454$, de 11 de agosto de 1981, criou a carreira de Procurador Fiscal e organizou a competência da Procuradoria Fiscal do Estado. O Decreto ${ }^{\circ} 21.559$, de 11 de setembro de 1981, dispôs sobre a estrutura da Procuradoria Geral do Estado. A Emenda Constitucional ${ }^{\circ} 20$, de 8 de maio de 1982, alterou os arts. 88 a 92 da Constituição do Estado; pela nova redação que deu ao art. 91, restringiu o Ministério Público às suas funções típicas, com a exclusão da representação judicial dos entes públicos.

A Lei $n^{\circ}$ 9.724, de 30 de novembro de 1988, dispôs sobre a Procuradoria-Geral do Estado ressalvando no seu art. $3^{\circ}$ que a assistência jurídica, nos assuntos relacionados com atos praticados pelo Poder Legislativo ou pela sua administração, competiria ao órgão próprio da Assembléia Legislativa. Em $1^{\circ}$ de setembro de 1990 foi 
publicada a Resolução n 5.086 da Assembléia Legislativa do Estado de Minas Gerais que criou o cargo de Procurador, atribuindo-lhe poderes para "a representação da Assembléia em Juizo ou fora dele, por delegação de poderes; a representação do Estado no processo judicial que versar sobre ato praticado pelo Poder Legislativo ou por sua administração; prestação de assessoramento de natureza jurídica quando determinado pelo titular do órgão; emissäo de pareceres de natureza jurídica sobre matéria administrativa ou institucional, assim como elaboraçāo de minutas de editais, contratos, regulamentos e outros documentos", entre outros. Hoje a representação da Assembléia Legislativa, por sua Procuradoria. encontra fundamento legal no art. 76 da Lei Complementar estadual $n^{\circ} 30$.

Enfim, após a Constituição Federal de 1988 e a Constituição do Estado de 1989 as principais disposições atinentes à Procuradoria-Geral do Estado e à Procuradoria-Geral da Fazenda Estadual (antiga Procuradoria Fiscal) foram consolidadas respectivamente nas Leis Complementares $\mathrm{n}^{\circ} 30$ e 35 .

\section{O Art. 132 da Constituição Federal}

O art. 132 é a sede constitucional da representação judicial e da consultoria jurídica dos Estados-membros. Sua inserção no corpo da Constituição Federal uniformizou, em relação a eles, os elementos essenciais atinentes ao tema de que cuida. Vale dizer: em razão da proeminência da Constituição Federal na ordem jurídica, é irregular qualquer norma que lhe contrarie o sentido. Logo, aplicando-se indistintamente a todos os Estados-membros, de sua observância resulta a igualdade do estatuto normativo básico da representação judicial e da consultoria jurídica dos Estados.

A denominação dos representantes judiciais e dos consultores jurídicos dos Estados é o primeiro elemento normativo que advém do texto constitucional: "Procuradores dos Estados" (no Distrito Federal: Procuradores do Distrito Federal) é a expressão que distingue os membros da carreira. Desconformes em relação à Constituição, tornaram-se outras expressões que comumente serviam à designação dos representantes judiciais e dos consultores jurídicos dos Estados-membros: "advogados do Estado", "assessores jurídicos", "consultores jurídicos" etc. O termo "Procuradores" revela a qualidade de representantes, de mandatários, e, por consequiência, do vínculo de representação que essa categoria de agentes possui com a pessoa política que também é expressamente designada: o Estado ${ }^{14,15}$.

14 O aprimoramento da designação dos representantes judiciais e dos consultores jurídicos do Estado. tanto quanto a criação de órgãos com funções especializadas, foi gradativo. Em Minas Gerais, até a promulgação da Emenda Constitucional $n^{\circ} 20$ que alterou a disciplina do Ministério Público na Constituição de 1970, a designação "Procurador-Geral do Estado" era referida ao Chefe do Ministério Público, e a designação "Procuradores do Estado" dizia respeito aos membros do Ministério Público que compunham o Conselho Superior do mesmo órgão (cf. inciso I e II do art. 88 da Constituição do Estado de Minas Gerais de 1967, com a redação que lhe foi dada pela Em. Const. $n^{\circ} 1$ de 1970). 
O segundo elemento normativo do artigo 132 da Constituição Federal é a determinação de que os Procuradores dos Estados sejam organizados em carreira acessível apenas através de concurso público de provas e títulos.

Para sublinhar o que há de reforço à idéia da unicidade no conceito de carreira, vale trazer à colação a lição de Hely Lopes Meirelles no seu clássico Direito Administrativo Brasileiro: "carreira é o agrupamento de classes da mesma profissão ou atividade, escalonadas segundo a hierarquia do serviço, para acesso privativo dos titulares dos cargos que a integram. O conjunto de carreiras e de cargos isolados constitui o quadro permanente do serviço dos diversos Poderes e órgãos da Administração Pública. As carreiras se iniciam e terminam nos respectivos quadros" 16.

$\mathrm{O}$ conceito de quadro complementa a idéia da unicidade: "quadro é o conjunto de carreiras, cargos isolados e funções gratificadas de um mesmo serviço, órgão ou Poder. O quadro pode ser permanente ou provisório, mas sempre estanque, não admitindo promoção ou acesso de um para outro" 17.

Ao dispor sobre a forma de ingresso na carreira, a mesma idéia aflora: "concurso público de provas e títulos" é a expressão gravada na Constituição, bem afinada com o disposto no inciso II do art. 37 da mesma Carta. O singular indica o que já se descortinara com a análise dos demais termos do art. 132: há um só concurso para ingresso na carreira de Procurador do Estado. Essa assertiva é também decorrência lógica do fato de ser o concurso o único meio de ingresso na carreira e da unicidade desta.

Por sua vez, essa forma necessária e institucional de investidura na carreira de Procurador de Estado enfatiza a circunstância de que a indisponibilidade peculiar ao interesse público demanda independência e autonomia na atuação desses agentes públicos frente à administração pública e ao Governo. Nesse sentido a lição de BERNARDO SESTA: “são incompatíveis com a caracterização da Advocacia do Estado, salvo em hipóteses excepcionais, as formas de investidura marcadas pela precariedade, tais como o comissionamento, a contratação e qualquer outra modalidade de admissão de Advogados para o exercício dessa competência, que os deixe sujeitos ao nuto de quem os tenha nomeado admitido ou contratado" 18.

De acordo com a nova redação do art. 132 da Constituição Federal, o concurso público de ingresso na carreira de Procurador do Estado deve contar com a participação da Ordem dos Advogados do Brasil em todas a suas fases, à semelhança do que já ocorria nos concursos públicos de ingresso na magistratura e no Ministério Público.

As funções expressamente atribuídas aos Procuradores dos Estados são o terceiro elemento normativo do art. 132: a representação judicial e a consultoria jurídica.

A representação judicial encontra seu regulamento no Código de Processo Civil, no Estatuto da Advocacia e da OAB e em outras leis extravagantes. Tem, portanto,

15 O Estado, não o Administrador ou o Governo do Estado. Cf. $n^{\circ} 5$, infra.

16 MEIRELLES, Hely Lopes. Direito Administrativo Brasileiro. 14 ed. São Paulo: Revista dos Tribunais. 1989. p. 360.

17 MEIRELLES, Hely L. Op. cit., loc. cit.

18 Op. cit., p. 198. 
seus contornos muito bem delineados na legislação ordinária. Para exercê-la é necessária a capacidade postulatória, isto é, de acordo com o art. $1^{\circ}$. incisos I e II da Lei $n^{\circ} 8.906 / 94$, seja cometida a advogado regularmente inscrito nos quadros da Ordem dos Advogados do Brasil não submetido a impedimento ou proibição de advogar.

A representação judicial é a que se dá no foro, perante a autoridade judiciária. Caracteriza-se pela postulação que é o ato de pedir ou exigir a prestação jurisdicional do Estado. É a função tradicional, historicamente cometida à advocacia ${ }^{19}$.

Ensina MOREIRA NETO: "a advocacia postulatória é a expressão privativa das funções essenciais à justiça, destinando-se a suscitar a atuação de qualquer dos Poderes do Estado, em especial o Judiciário, para a correção da injuridicidade. Admite por suposto, uma forma passiva, na qual a função é exercida sob demanda do interessado, e uma forma ativa, na qual ela é exercida ex-officio, por imposição da lei" ${ }^{20}$.

Conforme CRETELA JÚNIOR, a representação judicial "é a prática, em juizo, de atos de outrem, o mandante, neste caso, os Estados ou o Distrito Federal. $O$ Distrito Federal e cada um dos Estados-membros da Federação são credenciados pela Constituição a indicar os respectivos Procuradores para que os representem. em juízo, na qualidade de autores, réus, assistentes, opoentes (...)" 21.

Já a consultoria jurídica é, ainda nas palavras do mesmo autor, "função por excelência administrativa, ou, de modo mais específico, função consultiva, que, em essência, consiste no estudo do assunto e emissão de opinião, ou parecer" ${ }^{22}$.

Ou, nas palavras de MOREIRA NETO: " a advocacia consultiva é a expressão preventiva dessas funções, destinando-se a evitar o surgimento ou a permanência de agressão à ordem jurídica - a injuridicidade - como quer que ela se apresente, decorra de ação ou de omissão, na órbita privada ou pública. Admite uma forma de atuar passiva, na qual a função é provocada pelo interessado, e uma forma ativa, na qual é exercida sem provocação, em caráter fiscalizatório" 23.

Quanto à matéria, os limites epistemológicos da atuação dos Procuradores dos Estados envolvem todo o conhecimento pertinente às ciências jurídicas, compreendendo a Dogmática Jurídica, a Teoria Geral do Direito, a Sociologia Jurídica etc. É o que se deflui dos termos expressos da Constituição, e o que se compadece com as funções que lhes foram outorgadas. Dentro desse vasto campo jurídico, inexiste qualquer restrição à competência dos Procuradores dos Estados quanto à matéria da representação judicial ou da consultoria jurídica: administrativa, constitucional, cível, tributária, criminal etc. Qualquer que seja o tema sobre o qual versar a repre-

19 LÔBO, Paulo L. N. Comentários ao Novo Estatuto da Advocacia e da OAB Brasília: Brasília Jurídica. 1994. p. 21.

20 MOREIRA NETO, Diogo de F. Op. cit. p. 21

21 CRETELLA JR., José. Comentários à Constituição de 1988. p. 3.340-3.341.

22 Op. cit., loc. cit.

23 MOREIRA NETO, Diogo de F. Op. cit. p. 21 
sentação judicial e a consultoria jurídica referidas no art. 132 da Constituição Federal, devem ter como agentes os Procuradores dos Estados.

Vale relembrar que não são da competência das Procuradorias dos Estados os assuntos que se referem ao Estado-ordem jurídica (em oposição ao Estado-pessoa jurídica). A defesa da ordem jurídica estatal compete ao Ministério Público, nos termos do art. 127 e ss. da Constituição Federal (cf. $\mathrm{n}^{\circ} 1$, supra).

Além das duas funções explicitamente previstas na Constituição, outra de importância institucional aguda toca aos Procuradores do Estado: o exercício do controle interno da legalidade estatal. Pela sua importância, e por resultar de uma análise sistemático-teleológica, será tratada adiante (cf. ns. 4 e 5, infra).

No aspecto subjetivo, o artigo 132 da Constituição Federal, determina que as funções exercidas pelos Procuradores dos Estados têm como destinatários típicos os respectivos estados federados.

É da competência e atribuição exclusiva dos Procuradores dos Estados a representação judicial e a consultoria jurídica de todos os órgãos da administração direta, uma vez que esses não possuem personalidade jurídica distinta: os atos por eles praticados são atos de Estado, diretamente, sem mediação.

Como visto (cf. $\mathrm{n}^{\circ} 1$, in fine, e $\left.\mathrm{n}^{\circ} 4\right)$, o interesse público estatal não se limita à administração direta. Por isso, sempre que, nas entidades da administração indireta ou até nas entidades da esfera privada, surgir questão de natureza jurídica que reclame suas funções típicas, caberá, junto a esses entes, a intervenção dos Procuradores dos Estados.

Completa-se o estatuto constitucional dos Procuradores dos Estados com a previsão de estabilidade na carreira após três anos de efetivo exercício, mediante avaliação de desempenho pelo órgão que deverá ser criado ou indicado pela lei, depois de apresentado relatório circunstanciado pela respectiva corregedoria.

Os elementos normativos analisados induzem à unicidade orgânica da representação judicial e da consultoria de cada unidade federada em seu respectivo território, assegurada pelos elementos que compõem o estatuto básico da carreira de Procurador de Estado: a) unicidade da denominação da carreira de "Procurador do Estado"; b) unicidade da carreira e de sua respectiva forma de ingresso; c) inexistência de limitação de competência no tocante à matéria; d) exclusividade subjetiva do ente a quem se dirigem tanto a representação judicial quanto a consultoria jurídica.

\section{Prerrogativas Constitucionais Implícitas dos Procuradores dos Estados: o Controle da Legalidade e a Organicidade Funcional}

O enunciado do art. 132 da Constituição Federal não exaure o conteúdo normativo constitucional sobre a representação judicial e a consultoria dos Estados. Exsurgem de uma análise sistemático-teleológica importantes prerrogativas imprescindíveis à aferição das responsabilidades dos Procuradores de Estado diante do quadro institucional do País. 
A função de controle da legalidade dos atos da Administração Pública, na qualidade de provedoria da Justiça, e a independência funcional são atributos que tocam aos Procuradores de Estado de forma implícita ${ }^{24}$.

O controle da legalidade dos atos administrativos é, ao lado da limitação de competência, uma das técnicas de contenção do Poder.

A garantia da submissão da Administração Pública à ordem jurídica é efetivada pelo controle de suas atividades. Distinguem-se, em princípio, um sistema informal, de controle difuso, realizado pela sociedade, e um sistema formal, de controle concentrado, realizado pelos órgãos estatais. O controle estatal qualifica-se conforme o órgão que o realiza: administrativo, legislativo e jurisdicional. Porque a Administração Pública realiza-se preponderantemente na esfera do Poder Executivo, o controle administrativo "é um autocontrole dentro da Administração Pública. Tem por objetivos corrigir os defeitos de funcionamento interno do organismo administrativo, aperfeiçoando-o no interesse geral, e ensejar reparação a direitos ou interesses individuais, que possam ter sido denegados ou preteridos em conseqüência de erro ou omissão na aplicação da lei" 25 .

O controle dos atos da Administração Pública é uma exigência do princípio da legalidade, que, positivado no inciso II do art. $5^{\circ}$ da Constituição Federal, já merecera a reflexão de SEABRA FAGUNDES: "todas as atividades da Administração Pública são limitadas pela subordinação à ordem jurídica, ou seja, à legalidade. $O$ procedimento administrativo não tem existência jurídica se the falta, como fonte primária, um texto de lei. Mas não basta que tenha sempre por fonte a lei. É preciso, ainda, que se exerça segundo a orientação dela e dentro os limites nela traçados" 26.

Mas a legalidade não é mais o único parâmetro ético do controle. Ao lado desse, convivem ainda, em nosso ordenamento, o controle da legitimidade e o da licitude. A legitimidade refere-se à conformação do ato com a vontade da sociedade democraticamente manifestada. Tem seu fundamento normativo no parágrafo único do art. $1^{\circ}$ da Constituição Federal, e na própria designação "Estado Democrático de Direito" contida no caput do art. $1^{\circ}$ da Constituição Federal. A licitude diz respeito à submissão do Poder à moralidade, e revela-se em diversos dispositivos do texto constitucional, como é exemplo o caput do art. 37.

O controle administrativo que o Poder Executivo exerce dos seus próprios atos, pode também por este fato ser designado como "controle interno", sendo "externo", em relação ao Executivo tanto o controle exercido pelo Poder Legislativo quanto o exercido pelo Poder Judiciário. Também é externo o controle que a Administração direta exerce sobre a indireta.

MARIA SYLVIA ZANELLA DI PIETRO destaca dois aspectos concernentes ao controle dos entes descentralizados: a auto-administração, caracterizada pelo direito de exercerem, com independência, o serviço que lhes foi outorgado por lei,

24 Sobre "controle" na União, cf. arts. 13 e 14 do Dec.-Lei n' 200 de 1967; sobre "controle" no Estado de Minas Gerais, cf. Lei Delegada $n^{\circ} 05$ de 1985, arts. 45 a 48.

25 FAGUNDES, Miguel S. O Controle dos Atos Administrativos pelo Poder Judiciário. 3 ed. Rio de Janeiro: Forense, 1957. p. 121. Negrito nosso.

26 FAGUNDES, Miguel S. Op. cit. p. 113 
oponível à própria pessoa política que os instituiu; e o dever de realização do serviço, que os põe sob a fiscalização do poder público. Por isso, conclui: "é essencial entender-se a extensão do controle sobre os entes descentralizados; ele só vai até onde não ofenda a capacidade de auto-administração delimitada por lei; por sua vez, essa capacidade de auto-administração vai até onde não esbarre com os atos de controle previstos em lei" ${ }^{27}$.

Outras classificações de importância para a compreensão do tema são as que levam em conta: o momento da realização do controle, o aspecto da atividade administrativa a ser controlada e a finalidade imediata do controle. Quanto ao momento, o controle pode ser prévio, concomitante ou posterior. Quanto ao objeto, pode ter em vista a legalidade ou o mérito. $O$ controle da legalidade cabe aos três Poderes; o do mérito à Administração e, limitadamente, ao Poder Legislativo. Quanto à finalidade imediata o controle pode ser de fiscalização ou de correção.

O controle administrativo interno realiza-se ora pela aplicação do princípio da hierarquia, ora pela atuação de órgãos especializados.

Pelo princípio da hierarquia, pode o órgão superior da Administração em relação aos que lhes são subordinados: rever os atos, delegar e avocar atribuições e aplicar as penas disciplinares previstas em lei. A inferioridade hierárquica confere aos subordinados o dever de obediência. O controle hierárquico pode ser prévio, concomitante ou posterior; faz-se ex officio ou mediante provocação.

A crescente complexidade do aparelho estatal, a maior complexidade técnica das questões que tocam à Administração, a multiplicação das categorias de interesses e o incremento das exigências éticas por parte da sociedade tornaram insuficiente o controle baseado no princípio da hierarquia.

Essa evolução já foi demonstrada em melhores termos por MOREIRA NETO: "O Poder Público, de início concentrado e inespecializado, sofre um milenar processo evolutivo, desde suas primeiras e rudimentares manifestações, até que, com crescente nitidez, vão-se distinguindo funções específicas, destacando-se a legislativa da executiva e, mais tarde a judiciária.

Mas, ao mesmo tempo, no correr desse processo criam-se órgãos para exercêlos, agregando-se e conformando, pouco a pouco, complexos orgânicos. Órgãos e funções que originalmente se confundiam, desenvolveram-se e diferenciaram-se, até que, na linha da clássica tripartição de MONTESQUIEU, sedimentaram-se os três Poderes: Legislativo, Executivo e Judiciário, caracterizados, como hoje é pacífico, mais pela ênfase dada a certas funções que pela exclusividade de seu desempenho.

(...) Os últimos avanços da teoria constitucional enfatizaram, finalmente, a importância da chamada função de controle, para o exercício da qual concorrem os Poderes e a própria sociedade" 28,29 .

Prosseguindo sua análise, MOREIRA NETO diz que, com a devolução do poder à sociedade, paralelamente à diversificação das categorias de interesses e de seus

27 DI PIETRO, Maria S. Z. Direito Administrativo. 5 ed. São Paulo: Atlas, 1995. p. 345.

28 MOREIRA NETO, Diogo de F. Op. cit. p. 17.

29 Cf. também, nota de rodapé $n^{\circ} 9$. 
pólos de exercício, " multiplicaram-se e especializaram-se as funções de controle: preventivas e repressivas; fiscalizatórias, postulatórias e corretivas; parlamentares, administrativas e judiciárias".

Essa maior complexidade substantiva e formal, continua, "exigiu a extensão do princípio da defesa técnica, para que se pudesse manter a igualdade de oportunidade, a plenitude do direito de defesa e a observância do devido processo legal - tudo constitucionalmente assegurado" 30 .

$\mathrm{O}$ aprimoramento técnico (jurídico) tornou-se, portanto, imprescindível ao exercício das funções essenciais à Justiça. E, prosseguindo na linha traçada por MOREIRA NETO, o exercício de quaisquer das funções atribuídas aos Procuradores do Estado, sejam as explícitas, de representação judicial e de consultoria, seja a implícita, de controle dos atos administrativos, demanda um mínimo da necessária consistência técnica sob pena de inviabilizarem-se os fundamentos constitucionais do Estado Democrático de Direito.

A reunião dos agentes dotados de conhecimentos técnicos necessários à realização dessas funções em um único órgão, atende à melhor organização e divisão do trabalho, possibilita a coordenação e a cooperação entre os agentes, facilita o controle de suas atividades e realiza o modelo burocrático que a própria Constituição traçou para a organização administrativa. A essa concentração de funções em um único órgão, temos nos referido como "organicidade funcional", sendo uma das peculiaridades da Advocacia de Estado, como um todo, e das Procuradorias de Estado, particularmente.

Por tais motivos, tem razão o administrativista MOREIRA NETO ao afirmar que: "as funções essenciais à justiça se constituem num conjunto de atividades políticas preventivas e postulatórias através das quais interesses juridicamente reconhecidos são identificados, acautelados, promovidos e defendidos por órgãos tecnicamente habilitados, sob garantias constitucionais" 31.

Tais argumentos demonstram os fundamentos teleológicos da institucionalização das Procuradorias estaduais como órgãos, tanto quanto o Ministério Público e a Defensoria Pública, para o exercício dos atos de sua competência privativa. A organicidade funcional é prerrogativa dos Procuradores de Estado explicitamente consagrada pelo art. 69 dos ADCT da Constituição Federal, que menciona as "Procuradorias-Gerais ou Advocacias-Gerais" dos Estados.

A organicidade funcional não seria suficiente, no entanto, para que os Procuradores de Estado exercessem, em sua plenitude, o controle da legalidade dos atos administrativos. Para tanto, outra condição necessária infere-se também a partir da Constituição Federal: a independência funcional.

\section{Prerrogativas Constitucionais Implícitas dos Procuradores dos Estados: o Controle da Legalidade e a Independência Funcional}

A autonomia ou independência funcional, sendo outra prerrogativa implícita da

30 MOREIRA NETO, Diogo de F. Op. cit. p. 20. Negrito nosso.

31 MOREIRA NETO, Diogo de F. Op. cit. p. 20. Negrito nosso. 
Advocacia de Estado, também reforça a idéia de sua competência para o exercício do controle da legalidade. É, nas palavras de MOREIRA NETO, "a insujeição das procuraturas constitucionais a qualquer outro Poder do Estado em tudo o que tange ao exercício das funções essenciais à Justiça" ${ }^{32}$. Significa a liberdade moral e intelectual de que é dotada necessariamente a Advocacia de Estado. Sua existência se perfaz no nível constitucional e é aferível por diversos meios.

O primeiro é o elemento gramatical, a referência feita no art. 132, assim como em diversos outros dispositivos, ao "Estado" ("Procuradores do Estado e do Distrito Federal"). É o que enfatiza BERNARDO SESTA, grifando a preposição: "mas a característica especial da Advocacia do Estado sobressai, evidentemente, no que diz respeito ao patrocínio judicial do interesse público, porque nessa atividade, os agentes dela encarregados atuam em nome do Estado" ${ }^{33}$.

É suficiente a referência ao Estado para inferir-se que, no exercício de suas atribuições constitucionais, têm os Procuradores de Estado o compromisso maior com a ordem constitucional, seus princípios, suas instituições. Logo, a vontade manifestada pelo administrador somente interfere na atividade dos representantes judiciais dos Estados, enquanto se mantém nos estritos limites da autorização legal ou constitucional.

Portanto, mais uma vez tem razão BERNARDO SESTA quando afirma: “é secundário o fato de que o administrador manifeste sua preferência por determinada argumentação ou determinada postura em juizo; é irrelevante tal manifestação porque essa argumentação só chega em juízo através do Advogado do Estado e se ele a perfilhar. Em outras palavras: chega porque ele a perfilhou.

O Advogado do Estado, no exercício de sua função básica, não fala ao administrador para assessorá-lo; fala pelo Estado no processo em que este for parte, vinculando-o.

Usando da mesma alocução figurativa antes empregada, o Advogado do Estado, atuando em juizo, expressa, no processo, a vontade do Estado" ${ }^{34}$.

A independência funcional dos Procuradores de Estado resulta também das características peculiares à própria advocacia: beneficia-lhes a garantia estampada no art. 133 da Constituição Federal, isto é, são invioláveis por seus atos e manifestações no exercício da profissão. Por outro lado, a regulamentação legal da advocacia reflete sua aversão à hierarquia (cf. Lei 8.906, Estatuto da Advocacia e da OAB, art. $6^{\circ}$ ). A lei, ao reafirmar a independência do advogado, garantiu a existência da advocacia, pois aquele traço lhe é ínsito, como já ensinava o Procurador-Geral do Estado de Minas Gerais, Professor JOSÉ OLYMPIO DE CASTRO FILHO: "independência quer dizer, gramatical e filosoficamente, liberdade, livre-arbitrio, não sujeição a outros, nem a idéias de outros.

E isso mesmo é o que a advocacia naturalmente acaba proporcionando aos que a praticam, porque o advogado a ninguém está sujeito, de ninguém depende, é livre

32 MOREIRA NETO, Diogo de F. Op. cit. p. 27.

33 SESTA, Mário B. Op. cit. p. 197.

34 Op. cit. p. 197. 
de se determinar, eis que a sua sujeição, via de regra, é a muitos, colocados em situação de se não tornarem um só, e apenas está constrangido a se determinar pelas idéias, concepções, princípios ou rumos que a sua própria inteligência lhe dita como aconselháveis" 35 .

SÉRGIO DE ANDRÉA FERREIRA também ressaltou a independência funcional, não só dos Procuradores de Estado, mas de todos os membros das carreiras que desempenham as funções essenciais à justiça, por outro argumento, o de serem "agentes políticos" ${ }^{36}$. O autor justifica sua tese afirmando que as funções essenciais à Justiça na Constituição Federal foram inseriłas no Título IV, "Da Organização dos Poderes", em capítulo independente, ao lado dos capítulos que tratam dos Poderes Legislativo, Executivo e Judiciário. Raciocina: "ao caracterizar cada um desses organismos políticos, a CF caracteriza-os como instituições, e, assim, como estruturas dotadas de unidade e independência (no art. 127, sobre o MP, tais atributos são expressamente referidos). Aliás, essa individualidade, essa identidade, essa independência é que levaram a retirar essas instituições do âmbito dos Poderes Políticos tradicionais. Mesmo a Advocacia-Geral da União e as Procuradorias locais, nas suas funções de representação das pessoas jurídicas político-federativas, e de consultoria assessoramento jurídico do Poder Executivo, fazem-no com independência funcional e de fora desse Poder ou de qualquer um dos demais" ${ }^{37}$.

Por sua vez, a independência funcional evidencia que o único vínculo hierárquico que liga as Procuradorias de Estado ao Poder Executivo, é o de natureza administrativa. Tanto a independência funcional quanto a subordinação administrativa, exercitam-se de acordo com o modelo adotado pela constituição estadual e pela legislação complementar e ordinária. O fato dos Procuradores do Estado terem suas funções atreladas à observância da Constituição e das leis, e somente a elas, basta, por si só, para assegurar-lhes o controle da legalidade administrativa.

Em outras palavras: porque essa autonomia é conferida pela Constituição $\mathrm{Fe}$ deral, cabe às Procuradorias das unidades federadas o controle da legalidade, independentemente do disposto nas respectivas constituições e leis locais, que, no entanto, podem ampliar sobremaneira sua capacidade de atuação.

A decorrência lógica da independência funcional, e consectário da função de controle administrativo das Procuradorias estaduais, é a imparcialidade da atuação desses órgãos frente aos atos do Administrador. Como na representação judicial e na consultoria jurídica a proteção recai sobre o interesse público, a vitória desse será sempre a execução justa da lei, mesmo que, em alguns casos, a realização da Justiça implique o reconhecimento de equívocos cometidos pela própria Administração.

Desse modo, a independência funcional vincula-se intimamente à proteção dos direitos individuais e às condições de seu exercício junto ao Poder Judiciário.

35 CASTRO FILHO, José O. de. Prática Forense, v. I. 2 ed. Rio de Janeiro: Forense, 1977. p.22-23. 36 FERREIRA, Sérgio A. Comentários à Constituição, v. 3. Rio de Janeiro: Freitas Bastos. p. 112-113.

37 Op. cit. p. 12. 
O exercício do controle dos atos administrativos pelas Procuradorias estaduais faz-se dentro da competência típica desses órgãos: a representação judicial e a consultoria jurídica. Não exclui, é óbvio, o exercício concomitante de outras formas de controle seja o informal, seja o formal, por outros órgãos estatais. É o que esclarece a Procuradora do Estado do Rio de Janeiro, CLEIA CARDOSO: "É de se notar, que nada impede a acumulação de controle sobre os mesmos atos, ainda porque, cada tipo de controle tem sua natureza própria e destinação específica.

Assim, por exemplo, uma ilegalidade orçamentária, pode ser objeto de controle interno orçamentário (Administraçāo Pública), do controle externo orçamentário (Tribunal de Contas), de controle interno da Procuradoria do Estado e, se isto configurar um ilícito penal, caberá, ainda, o controle por parte do Ministério Público" ${ }^{38}$.

O controle da legalidade pelas Procuradorias de Estado tem como peculiaridade a prevenção. Tanto quanto as funções dos Procuradores de Estado são desempenhadas no seio da Administração, o controle da legalidade a seu cargo ocorre no nascedouro da atuação administrativa, evitando prejuízos para o Erário, danos aos direitos subjetivos dos administrados e, em geral, ofensa aos princípios constitucionais da administração pública.

A organicidade e a autonomia funcionais das Procuradorias estaduais são os princípios constitucionais reciprocamente complementares, imprescindíveis à consecução de sua função implícita mais nobre que consiste no controle interno da legalidade dos atos administrativos.

\section{A Inconstitucionalidade das Normas Infringentes ao Princípio da Unicidade no Estado de Minas Gerais ${ }^{39}$}

No Estado de Minas Gerais, desde a promulgação da Lei $n^{\circ} 5.047$, em 27 de novembro de 1968, ocorre duplicidade orgânica quanto à representação judicial e à consultoria jurídica do Estado, em razão da criação, pela citada lei, da Procuradoria Fiscal do Estado, órgão subordinado à Secretaria da Fazenda, com competência sobre a matéria tributária, uma vez que as demais matérias continuaram sob os cuidados do Departamento Jurídico do Estado (cf. supra, $\mathrm{n}^{\circ} 2$ ).

Essa duplicidade continuou a existir mesmo depois da vigência da Constituição Federal de 1988 , tendo sido determinada pelo $\S 2^{\circ}$ do art. 128 da Constituição do Estado de Minas Gerais de 1989, nos seguintes termos: "nos processos judicial e administrativo que tratem de matéria tributária, a representação do Estado incumbe à Procuradoria Geral da Fazenda Estadual, que a exercerá por seus Procuradores".

O dispositivo da Constituição do Estado de Minas Gerais transcrito desafia a declaração de inconstitucionalidade porque: a) reduz a competência dos Procuradores

38 CARDOSO, Cleia. O Controle Interno de Legalidade pelos Procuradores do Estado. in: Rev. de Informação Legislativa, $n^{\circ} 118$, abr./jun. 1993. Brasília. p. 157-166, espec. p. 164.

39 Antecedentes normativos da Procuradoria-Geral da Fazenda, cf. $\mathrm{n}^{\circ} 2$ supra. 
do Estado. retirando-lhes a matéria tributária; b) cria outra designação para representantes judiciais e consultores jurídicos do Estado; c) cria carreira paralela e permite provimento de cargos por concurso distinto do concurso para a carreira de Procurador do Estado.

Além dos atributos relativos à competência, à designação, à forma de ingresso, e à organicidade funcionais, vimos também que a referência subjetiva à pessoa representada, isto é, o Estado, corrobora o entendimento da unicidade da representação judicial e da consultoria jurídica dos Estados-membros (cf. supra, ns. 3 e 4). Assim, é de se observar que, apesar da denominação atribuída ao órgão "Procuradoria Geral da Fazenda Estadual" —, dúvida não há de que a representação que ele presta não é, senão ao próprio Estado de Minas Gerais, o que decorre da inexistência de personalidade jurídica por parte da Secretaria da Fazenda, que é órgão da administração direta do Estado ${ }^{40}$.

Cumpre lembrar que uma importante e significativa exceção ao princípio da unicidade encontra-se positivada no art. 69 dos Atos das Disposições Constitucionais Provisórias da Constituição Federal (ADCT): “Será permitido aos Estados manter consultorias jurídicas separadas de suas Procuradorias-Gerais ou Advocacias-Gerais, desde que, na data da promulgação da Constituição, tenham órgãos distintos para as respectivas funções".

A topologia do dispositivo indica que a exceção nele configurada veio atender a situações concretas, momentâneas. Por isso, JOSÉ AFONSO DA SILVA, depois de afirmar que os Procuradores de Estado são organizados em carreira dentro de uma estrutura administrativa unitária, menciona, exemplificativamente, o caso do Estado de Pernambuco. Nesse Estado, como deixa a entender, havia serviços de consultoria jurídica separados de sua Procuradoria-Geral, cuja manutenção, nessas condições, tornou-se possível mediante o art. 69 dos ADCT e apesar do disposto no art. 132 da Constituição Federal ${ }^{41}$.

Por ser uma exceção, infere-se que o art. 69 dos ADCT deve ser interpretado restritivamente. É o que nos ensinou o imprescindível CARLOS MAXIMILIANO: " as disposições excepcionais são estabelecidas por motivos ou considerações particulares, contra outras normas jurídicas, ou contra o Direito comum; por isso não se estendem além dos casos e tempos que designam expressamente" ${ }^{42}$.

40 A Lei Delegada n 05 do Estado de Minas Gerais, determina, em seu art. 6”: " a Administração Direta é constituída por órgãos sem personalidade jurídica, sujeitos a subordinação hierárquica, integrantes da estrutura administrativa do Poder Executivo e submetidos à direção superior do Governador do Estado". O dispositivo está incluído na Seção I, "Da Administração Direta", em cuja Subseção I, "Secretaria de Estado", consta o art. 7: "à Secretaria de Estado, como órgão central de direção e coordenação das atividades de sua área de competência, cabe exercer a supervisão geral dos órgãos subordinados e das entidades vinculadas".

41 SILVA, José A. da. Curso de Direito Constitucional Positivo. 9 ed. São Paulo: Malheiros. 1994. p. 540

42 Diz mais o autor: "O Código Civil explicitamente consolidou o preceito clássico - Exceptiones sunt strictissimoe interpretationis ('interpretam-se as exceções estritissimamente) - no art. $6^{\circ}$ da antiga Lei de Introdução, assim concebido: 'A lei que abre exceção a regras gerais, ou restringe direitos, só abrange os casos que especifica'. 
Atentos à regra hermenêutica e ao texto do art. 69 dos ADCT, verificamos que a exceção ao princípio da unicidade somente incide sobre as atividades de consultoria jurídica e, mesmo assim, quando já exercidas por órgãos separados das Procuradorias de Estado na data da promulgação da Constituição Federal.

A impedir qualquer entendimento extensivo da expressão "consultoria jurídica", está também o fato de que essa função foi claramente distinguida da de "representação judicial" pela Constituição Federal como já demonstramos no $\mathrm{n}^{\circ} 3$, supra: a consultoria jurídica é o assessoramento extrajudicial com vistas a auxiliar a administração na realização de suas atividades-fins, garantindo o controle da legalidade dos atos administrativos; serve também à fixação da segurança jurídica, firmando a interpretação a ser seguida pelo Estado quando mais de uma torna-se possível; a representação judicial é a que se dá no foro, quando, iniciado o processo, dele participa o Estado na qualidade de parte.

$\mathrm{O}$ art. 69 dos $\mathrm{ADCT}$, ao mesmo tempo em que limita a incidência do princípio da unicidade orgânica das Procuradorias estaduais, reafirma a existência do princípio, pois, somente regra admite exceção. Fosse permitido aos Estados, livremente, dispor sobre a organicidade funcional de suas Procuradorias-Gerais, não haveria razão para existir o dispositivo transitório, que seria redundante. Assim, a permissão a que faz referência o art. 69 dos ADCT somente faz sentido se existente a norma que proíbe genericamente a divisão das Procuradorias, ainda que implícita.

Com a instituição do princípio da unicidade da representação judicial dos Estados-membros pela Constituição Federal de 1988, revogadas foram quaisquer normas que, anteriores, conflitassem com o mencionado princípio (inconstitucionalidade superveniente). Cumpria ao constituinte derivado ao regulamentar a matéria, efetivar a adaptação dos preceitos ao novel princípio da unicidade. Não o tendo feito, fez incorrer em inconstitucionalidade a Constituição do Estado de Minas Gerais, no tocante ao disposto no $\S 2^{\circ}$ do art. 128.

Revogados foram, portanto, os dispositivos das leis estaduais que, vigentes ao tempo da promulgação da Constituição Federal, determinavam a representação judicial do Estado por órgão distinto da já existente Procuradoria-Geral do Estado de Minas Gerais. E, sobretudo, inconstitucionais vieram a ser os dispositivos legais que, elaborados posteriormente à Constituição Federal, infringiram o princípio da unicidade, tais como os incisos I a V e XV, do art. $3^{\circ}$ da Lei Complementar Estadual $n^{\circ}$ $35^{43}$.

(...) A regra exarada no art. $6^{\circ}$ da Introdução ao Código Civil Brasileiro de 1916 não foi reproduzida em a nova Lei de Introdução (Decreto-lei $n^{\circ} 4.657$, de 4 de setembro de 1942). Tal proceder, porém, não importa em eliminarem virtualmente o brocardo vetusto: apenas assinala preferência pela corrente que exclui da legislação os ditames da Hermenêutica; deixa-os sobreviver no campo vasto e iluminado da doutrina. A idéia concretizada pelo art. $6^{\circ}$, de 1916, continua de pé, universal, firme em sua essência". (Cf. MAXIMILIANO, Carlos. Hermenêutica e Aplicação do Direito. 14 ed. Rio de Janeiro: Forense. 1994. p. 225, 226 e 227).

43 "Art. $3^{\circ}$. A Procuradoria-Geral da Fazenda Estadual, instituiçāo pertencente à estrutura orgânica da Secretaria de Estado da Fazenda, exerce funçōes essenciais à Justiça, nos termos da Constituição Federal, competindo-lhe: 
A matéria tem sido objeto de vários pronunciamentos por parte do Supremo Tribunal Federal. O entendimento abraçado por nossa Corte Constitucional, pela importância, será analisado à parte, após a apresentação de alguns argumentos que são levantados contra a unicidade e a refutação desses argumentos.

\section{Os Argumentos Contrários à Unicidade: a Simetria dos Textos Constitucionais}

O Direito, por regular a conduta humana e os interesses que lhes são subjacentes, é, por excelência, dialético. Assim, impossível seria, em matéria de tão largo alcance, não haver quem negasse o princípio da unicidade da representação judicial e da consultoria jurídica dos Estados-membros.

O primeiro argumento contrário ao princípio da unicidade afirma que, existindo no nível da União duplicidade da representação judicial e da consultoria jurídica, fundada no art. 131 e em seu $\S 2^{\circ}$ da Constituição Federal, por simetria ou semelhança a mesma possibilidade estender-se-ia aos Estados-membros.

Esse argumento não procede por dois motivos: em primeiro lugar, a duplicidade da representação judicial da União é relativa; em segundo, na representação judicial e na consultoria jurídica dos Estados é vedada a simetria em relação à regulamentação da representação judicial e da consultoria jurídica da União.

A Constituição Federal de 1988 criou a Advocacia-Geral da União para exercer a defesa de seus interesses em juízo, e para prestar-lhe a assessoria jurídica, retirando ao Ministério Público Federal essas atribuições. Seguiu o modelo italiano onde a defesa judicial dos interesses do Estado compete à "Avvocatura dello Stato", instituída em $1876 \mathrm{com}$ o nome de "Avvocatura Erariale", com funções distintas das do Ministério Público. Essa é a lição de PINTO FERREIRA: “A Advocacia do Estado na Itália tem amplas atribuições, constituindo um órgão diretamente subordinado ao governo. É a Avvocatura dello Stato, gozando cada dia de mais ampla proteção e amparo na organização constitucional italiana. É de ressaltar a peculiar situação jurídica e étic.x, moralmente fortalecida, como órgão de representação $e$ colaboração, fora do mecanismo burocrático intercalar e contraproducente.

I - representar o Estado de Minas Gerais, dentro e fora de seu território, perante qualquer Juizo ou Tribunal ou, por determinação do Governador ou do Secretário de Estado da Fazenda, em qualquer ato;

II - defender, judicial e extrajudicialmente, ativa e passivamente, os atos e as prerrogativas do Governador e do Secretário de Estado da Fazenda;

III - preparar informações, em ação direta de inconstitucionalidade, a serem prestadas pelo Governador do Estado;

IV - sugerir e minutar ação direta de inconstitucionalidade para o Governador do Estado;

$V$ - elaborar informaçôes ao Poder Judiciário em mandado de segurança e "habeas data" impetrados contra o Governador do Estado, o Secretário do Estado da Fazenda ou autoridade a ele subordinada;

$X V$ - zelar, em autos judiciais ou extrajudiciais, pelo recolhimento dos tributos estaduais". 
Subordinada diretamente ao presidente do Conselho de Ministros, a Advocacia do Estado possui um status semelhante ao do Conselho de Estado e ao da Corte de Contas.

É um órgão ao qual a lei confia a representação do Estado e também das autarquias, sendo-lhe também atribuída uma função jurídico-consultiva da administração que é entregue e confiada ao corpo técnico de advogados" ${ }^{4}$.

A lição nos ajuda a compreender os objetivos do constituinte ao determinar a existência da Advocacia-Geral da União e, com vistas a esse objetivo, também nos auxilia na compreensão da organização que lhe deu a Lei Complementar $n^{\circ} 73$, de 10 de fevereiro de 1993 (Lei Orgânica da Advocacia-Geral da União).

De acordo com a citada lei, a Advocacia-Geral da União é subordinada, direta e imediatamente, ao Advogado-Geral da União (art. $9^{\circ}$ ); a Procuradoria-Geral da Fazenda Nacional, por sua vez, tem subordinação dúplice: técnica e juridicamente, ao Advogado-Geral da União (art. $2^{\circ}, \S 1^{\circ}$, in fine), administrativamente, ao Ministério da Fazenda (art. 12); à primeira incumbe a representação judicial da União, junto aos tribunais e à primeira instância da Justiça Federal, comum e especializada (art. $9^{\circ}, \S \S 1^{\circ}, 2^{\circ}$ e $3^{\circ}$ ); à segunda, a apuração da liqüidez e certeza da dívida ativa da União de natureza tributária, a representação privativa da União, na execução de sua dívida ativa de caráter tributário; a representação e promoção da defesa e do controle dos interesses da Fazenda Nacional, nas entidades cujo capital participe a União; o exame prévio da legalidade dos contratos, acordos, ajustes, e convênios do interesse do Ministério da Fazenda; a representação da União nas causas de natureza tributária (art. 12, I, II, III e IV); bem como as atividades de consultoria e assessoramento jurídicos, no âmbito do Ministério da Fazenda (art. 13). A Lei Complementar $n^{\circ} 73$ criou também a Consultoria-Geral da União, igualmente compreendida no âmbito da Advocacia-Geral da União.

Portanto, a Procuradoria-Geral da Fazenda Nacional encontra-se no bojo da Advocacia-Geral da União (art. $2^{\circ}$ ), estando, inclusive, subordinada técnica e juridicamente ao Advogado-Geral da União (art. $2^{\circ}, \S 1^{\circ}$ ). Somente sob o aspecto administrativo é que ela se subordina ao Ministério da Fazenda (art. 12).

Não bastasse a inexistência de uma autonomia orgânica da Procuradoria-Geral da Fazenda Nacional em relação à Advocacia-Geral da União, nesse particular inexiste para os Estados qualquer dever de observância do modelo adotado pela União, em razão da autonomia de que são dotados, corolário essencial à configuração do Estado Federal proclamado no art. $1^{\circ}$ da Constituição Federal.

Um profundo estudo sobre o tema, foi elaborado pelo Professor da Faculdade de Direito da Universidade Federal de Minas Gerais, RAUL MACHADO HORTA, sob o título A Autonomia do Estado-Membro no Direito Constitucional Brasileiro, onde ensinou: "As normas de imitação exprimem a cópia de técnicas ou de institutos, por influência da sugestão exercida pelo modelo superior.

44 FERREIRA, Pinto. Comentários à Constituição Brasileira, $5^{\circ}$ v. São Paulo: Saraiva. 1992. p. 163. 
As normas de reprodução decorrem do caráter compulsório da norma constitucional superior, enquanto a norma de imitação traduz a adesão voluntária do constituinte a uma determinada disposição constitucional ${ }^{45}$.

$\mathrm{O}$ que se tem denominado simetria ou semelhança entre textos constitucionais estaduais e a Constituição Federal é a consequência da elaboração das normas de reprodução ou de imitação, tão bem distinguidas pelo eminente constitucionalista.

Pelo princípio da autonomia dos Estados-membros, sempre que for obrigatório para eles, qualquer que seja a matéria, aplicar o modelo adotado pela União, será por força de determinação expressa, explícita ou implícita. da Constituição Federal.

No tocante à representação judicial e à consultoria jurídica dos Estados, nem sequer liberdade política thes foi outorgada para que imitassem o modelo adotado pela União. A sugestão que pudesse hipoteticamente estar contida no art. 131 da Constituição Federal foi expressamente proibida pelos dizeres do art. 132 da mesma Constituição.

8. Os Argumentos Contrários à Unicidade: a Natureza Jurídica do Disposto no art. 132 da Constituição Federal; a Supremacia dos Interesses Defendidos pelo Governador; a Constitucionalidade das Procuradorias das Assembléias Legislativas; a Conveniência Político-Administrativa

É conhecido também o argumento de que o constituinte não teria incapacitado as entidades estatais para constituir mandatários ad judicia, porque essa matéria seria de Direito Processual enquanto o art. 132 da Constituição Federal seria norma de organização administrativa. Tal interpretação, contraria a supremacia das normas constitucionais sobre toda a ordem jurídica e labora por meio de distinção inexistente no texto constitucional. Não é, por isso, aceitável.

Outro argumento que se prende à natureza da matéria tratada no mencionado dispositivo é o que diz ser ele uma vedação endereçada ao Ministério Público dos Estados-membros e d s Distrito Federal, do exercício da advocacia pública, com a finalidade de operar, no nível estadual, a mesma separação de funções operada no nível da União. Essa interpretação torna o art. 132 mera repetição do que já se contém no inciso IX do art. 129, in fine. Também contradiz a topologia do dispositivo, que está situado na seção denominada "Da Advocacia Pública", ao lado da seção dedicada ao Ministério Público e sob o mesmo Título: "Das Funções Essenciais à Justiça". Como já exposto, a Constituição Federal, nos artigos 131 e 132, institucionalizou a advocacia pública e conferiu-lhe suas prerrogativas básicas.

Já se disse também que o Governador deve poder exercer as suas atribuições amplamente, inclusive na defesa daquilo que seja interesse do Estado, no âmbito do Poder Executivo. O argumento pretensamente busca compatibilizar essa idéia com o art. 132 da Constituição, concluindo que excepcionalmente seria possível a repre-

45 HORTA. Raul M. A Autonomia do Estado-Membro no Direito Constitucional Brasileiro. Belo Horizonte: Santa Maria. 1964. p. 192-193. Negrito nosso. 
sentação judicial dos Estados-membros por advogado que não seja Procurador do Estado. Esse argumento não leva em consideração o desenvolvimento histórico do Estado, no sentido do estabelecimento de meios de controle do exercício do Poder. Chega a aproximar o interesse público do interesse individual, obscurecendo a mediação que existe entre o interesse manifestado pelo Administrador e o interesse público aferível pelos princípios constitucionais e legais. Como já salientado, a Constituição Federal de 1988 fez. no nível formal, com que o Estado brasileiro alçasse os patamares da Democracia e da Justiça. Os limites que a exclusividade da representação judicial pelos Procuradores do Estado pode impor aos administradores são os traçados pela própria Constituição. consubstanciados no princípio da legalidade e da moralidade. Não ofendem a ordem jurídica. mas visam à sua proteção.

Há também quem enxergue nas procuradorias das Assembléias Legislativas estaduais, a negativa da vigência do princípio da unicidade orgânica. Embora tenha o Supremo Tribunal Federal decidido que o "Poder autônomo (mesmo não personalizado)" possa manter assessoria jurídica própria e admitido a capacidade processual das "Casas Legislativas", restringiu a representação judicial das mesmas, por seu corpo jurídico, "às hipóteses em que comparę̧a a Câmara a Juizo em nome próprio" ${ }^{46}$. A razão desse entendimento constou da Ação Direta de Inconstitucionalidade $\mathrm{n}^{\circ} 825$, do Amapá: "o reconhecimento da personalidade judiciária de órgãos não personalizados - em particular, dos corpos legislativos -, de relevo específico nas causas, a exemplo desta, em que se visa à composição jurisdicional do conflito entre poderes diversos da mesma entidade estatal ilide, em princípio, a força da impugnação à previsão da existência de uma Procuradoria da Assembléia Legislativa (art. 115), diversa da Advocacia do Estado, que se insere na estrutura orgânica do Executivo" + ?

Portanto, conforme esclarecido pelas decisões da Corte Constitucional brasileira, a existência de procuradorias de Assembléias Legislativas justifica-se pela possibilidade de ocorrerem conflitos entre poderes da mesma entidade estatal. As decisões repudiam, a contrario sensu, a existência de corpos jurídicos distintos no seio de um mesmo Poder, comprovando a necessidade constitucional da unicidade orgânica das Procuradorias estaduais.

Outro argumento lançado contra o princípio da unicidade é o da conveniência político-administrativa. Esse argumento exalta, em geral, os interesses fazendários dos Estados e busca justificar a existência de corpos jurídicos separados das Procuradorias-Gerais, com a divisão de sua competência, alegando eficácia na cobrança dos créditos de natureza tributária. Essa eficiência seria devida a uma maior proximidade com os setores da administração especializados na matéria, resultando na melhoria da comunicação interna ${ }^{48}$.

46 Julgamento da liminar da ADIN 1557-DF. RTJ 163/95.

47 DJU de 02/04/93.

48 Tome-se como exemplo, a tese apresentada pelo tributarista JOSÉ ALFREDO BORGES no XXIII Congresso de Procuradores de Estado, "A Experiência do Estado de Minas Gerais de uma Estrutura Partilhada da Representação do Estado em Juízo". Cf. XXIII Congresso de Procuradores de Estado - Teses. 1997. p. 503-510. 
Os argumentos dessa espécie pecam pela parcialidade. Antes de tudo, há de se ter em conta que, num Estado Democrático de Direito, as principais opções políticas, as de ordem estrutural, básicas, são aquelas tomadas pelo Poder Constituinte, adentradas no campo jurídico por via da Constituição. Uma vez feita constitucionalmente a escolha por determinado modelo, as elucubrações que tenham como objetivo quiestioná-lo ou têm em vista a reforma da Constituição, sendo políticas, ou têm em vista a pesquisa, a formação de conhecimento do tipo sociológico, econômico, administrativo etc. Em qualquer dos casos não se tratará de exercício da técnica jurídico-positiva.

Mas, mesmo no campo da sociologia e da política, tais argumentos mostram-se parciais, porque não levam em conta a multiplicidade dos interesses em questão. Frise-se: o princípio da unicidade não diz respeito apenas aos interesses fazendários dos Estados, não foi constitucionalmente estabelecido para contemplá-los com exclusividade e deve ser analisado em ângulos distintos e complementares, imprescindíveis à uma visão abrangente do tema.

Do ponto de vista dos membros da carreira, os Procuradores de Estado, a prática demonstra que a não observância do princípio da unicidade dificulta a comunicação entre os mesmos, trazendo graves repercussões no desempenho do serviço. Há interpenetração entre a representação judicial em matéria tributária e a representação judicial relativa às demais matérias. Assim, por exemplo, enquanto o Estado promove a excussão dos bens do devedor tributário, tais bens ficam sob a sua guarda ou vêm a integrar seu patrimônio, demandando a realização de medidas de conservação que não estão a cargo dos representantes dos interesses fazendários.

Outro exemplo está na perda das informações, pois, do mesmo modo como é vital para a representação judicial tributária o acesso a sistemas de informação da Secretaria da Fazenda, o acesso a eles serviria também ao melhor desempenho da defesa dos interesses do Estado em assuntos não estritamente fazendários.

Para o Estado, que é outro vértice de onde partem interesses essenciais, a violação da unicidade representa a necessidade da manutenção de duas ou mais estruturas para a execução do mesmo serviço. Para escapar ao incremento da despesa que a duplicidade por si só representaria, frequientemente os Estados, como é o caso de Minas Gerais, empregam os recursos humanos e materiais das secretarias (notadamente da Secretaria da Fazenda). Com isso, ficam as Procuradorias destituídas de condições mínimas para o exercício autônomo de suas atividades, comprometendo sua independência diante da Administração e, muitas vezes, o desempenho de suas funções.

Todos esses interesses, no entanto, tornam-se ínfimos quando comparados ao interesse público, não considerado abstratamente, como expressão morta que jaz em páginas de livros, mas na sua forma mais vívida que traduz os anseios, as esperanças e as conquistas maiores de um povo.

Retirar do texto constitucional o princípio da unicidade mediante uma interpretação contra legem, é desdenhar a lição da História, é aviltar a supremacia da Constituição e subtrair ao povo uma de suas maiores conquistas: a de ter na Procuradoria-Geral do Estado um órgão fortalecido na defesa das instituições democráticas. guardião da legalidade e da moralidade públicas, servil à Constituição, ao Estado Democrático de Direito e, por meio dele, aos anseios populares. 


\section{O Art. 132 da Constituição Federal na Interpretação do Supremo Tribunal}

Federal

Muitas têm sido as manifestações do Supremo Tribunal Federal sobre a representação judicial e a consultoria jurídica dos Estados-membros. Vejamos algumas delas pertinentes ao tema da unicidade.

A Ação Direta de Inconstitucionalidade (Adin) no 159 foi proposta pela Associação Nacional dos Procuradores de Estado (ANAPE) em fevereiro de 1990 sob o argumento de que nos anos anteriores à propositura da ação tinham sido admitidos no serviço do Estado do Pará, sem concurso, cerca de duzentos assistentes, assessores jurídicos e procuradores autárquicos, que os parágrafos $2^{\circ}$ e $4^{\circ}$ da Constituição do Estado do Pará transformaram em Consultores Jurídicos, com os mesmos direitos dos Procuradores do Estado, ao arrepio do disposto no artigo 37 da Constituição Federal e seus incisos II e XIII (moralidade da administração, exigência do concurso público e vedação das equiparações). Por maioria de votos, o Tribunal rejeitou a preliminar de ilegitimidade ativa ad causam, da requerente. No mérito, também por maioria de votos, o Tribunal julgou procedente a ação ${ }^{49}$.

A Adin $n^{\circ} 241$ foi proposta pelo Governo do Estado do Rio de Janeiro com o objetivo de ter declarada a inconstitucionalidade do art. 245 da Constituição daquele estado que conferiu ao Instituto Estadual de Terras e Cartografia a competência, para, por sua própria Procuradoria, promover ações discriminatórias de terras devolutas. O feito aguarda julgamento.

Outra Adin que aguarda julgamento é a de $\mathrm{n}^{\circ} 484$ em que o Governador do Estado do Paraná requereu a declaração da inconstitucionalidade das leis estaduais de ns. 9.422, de 5 de novembro de 1990 , e 9.525 de 8 de janeiro de 1991 sob a alegação de que, dentre outros dispositivos, essas leis ofenderiam o art. $132 \mathrm{da}$ Constituição Federal por criar carreira paralela à de Procurador do Estado com o nome Advocacia Especial do Estado, atribuindo-lhe, concorrentemente, competências exclusivas da Procuradoria do Estado. Outra inconstitucionalidade estaria na restrição ao ingresso na carreira de Assistentes Jurídicos e Advogados da administração direta e autárquica mediante concurso de efetivação (interno), tolhendo, assim, a realização de concurso público.

A Adin 824 foi proposta pela ANAPE contra a Lei ${ }^{\circ} 6.094$ do Estado de Mato Grosso, ao fundamento de que ela teria criado um "Grupo Especial de Advogados do Estado de Mato Grosso", com 48 cargos, integrado pelos ocupantes de cargos públicos de advogado na administração pública direta, autárquica e fundacional, com a atribuição primordial de prestar assessoramento jurídico ao órgão em que se encontrassem lotados, ou a outros órgãos públicos, a critério da administração. De acordo com a requerente, além de ferir os arts. $5^{\circ}$ e 37 - caput e incisos I e II -, a lei feriria o art. 132 da Constituição Federal. Requerida a liminar, por votação unânime, o Tribunal acompanhou o despacho do Ministro Sepúlveda Pertence que 
suspendera os efeitos dos dispositivos legais impugnados até decisão final. A ação aguarda julgamento de mérito ${ }^{50}$.

O Conselho Federal da Ordem dos Advogados do Brasil requereu a declaração de inconstitucionalidade dos arts. 12, caput, parágrafos $1^{\circ}$ e $2^{\circ}$, e 13 , incisos. I a V, todos da Lei Complementar $n^{\circ} 11$, do Estado do Espírito Santo, por meio da Adin $\mathrm{n}^{\circ} 881$, sob o argumento de que as normas questionadas tratariam da criação de cargos de Assessor Jurídico. de provimento em comissão, na esfera do Poder Executivo local. conflitando, por isso, com o art. 132 da Constituição Federal e com o art. 69 dos ADCT. Requereu-se a suspensão liminar dos dispositivos atacados. Na decisão da liminar. houve por bem o Supremo Tribunal Federal, por maioria de votos, deferir a medida. O Relator, Min. Celso de Mello, fundamentando seu voto afirmou: "O conteúdo normativo do art. 132 da Constituição Federal revela os limites materiais em cujo âmbito processar-se-á a atuação funcional dos integrantes da Procuradoria-Geral do Estado e do Distrito Federal. Nele contém-se norma que, revestida de eficácia vinculante e cogente para as unidades federadas locais, não permite conferir a terceiros - senão aos próprios Procuradores do Estado e do Distrito Federal, selecionados em concurso público de provas e títulos - o exercício intransferivel e indisponivel das funções de representação estatal e de consultoria juridica do Poder Executivo. (...) A exclusividade dessa função de consultoria remanesce, agora, na esfera institucional da Advocacia Pública, exercida, no plano dos Estados-membros, por suas respectivas Procuradorias-Gerais e pelos membros que as compõem.

Essa prerrogativa institucional, que é de ordem pública, encontra assento na própria Constituição Federal. Não pode, por isso mesmo, comportar exceçôes e nem sofrer derrogaçôes que o texto constitucional sequer autorizou ou previu" 51.

O Min. Néri da Silveira preferiu pôr em relevo o controle da legalidade exercido pelos Procuradores de Estado: “Penso que o art. 132 da Constituição quis, relativamente à Advocacia de Estado, no âmbito dos Estados-membros e do Distrito Federal, conferir às Procuradorias não só a representatividade judicial, mas, também, o exame da legalidade dos atos, e o fez com a preocupação de atribuir essa função a servidores concursados e detentores do predicamento da efetividade. $O$ grande objetivo foi o exame da legalidade dos atos do Governo, da Administração Estadual, a ser feito por um órgão cujos ocupantes, concursados, detenham as garantias funcionais. Isso conduz à independência funcional, para o bom controle da legalidade interna, da orientação da administração quanto a seus atos, em ordem a que esses não se pratiquem tão-só de acordo com a vontade do administrador, mas também conforme a lei.

Não quis a Constituição que o exame da legalidade dos atos da Administração Estadual se fizesse por servidores não efetivos. Daí o sentido de conferir aos Procuradores dos Estados - que devem se compor em carreira a ser todos concursados - não só a defesa judicial, a representação judicial do Estado, mas

50 R.T.J. $150 / 484$.

51 Boletim de Direito Administrativo. Novembro/97. p. 778-783. Em negrito no original. 
também a consultoria, a assistência jurídica. De tal maneira, um Procurador pode afirmar que um ato de Secretário, do Governador não está correspondendo à lei, sem nenhum temor de poder vir a ser exonerado, como admissivel suceder se ocupasse um cargo em comissão" 52 . A ação aguarda o julgamento de mérito.

A ANAPE ajuizou a Adin $n^{\circ} 1.557$ para atacar a Emenda $n^{\circ} 9$ à Lei Orgânica Distrital que dava nova redação aos arts. $1^{\circ} ; 57$, caput, $\S 1^{\circ}$, incisos I a V e $\S \S 2^{\circ}$ e $3^{\circ} ; 110 ; 111$ e 113 , caput e $\S 2^{\circ}$. Foi requerida medida liminar para suspender a vigência dos dispositivos atacados até a decisão do mérito. Em linhas gerais, a nova redação dos citados dispositivos visava conferir competência à Procuradoria-Geral da Câmara Legislativa para representar judicialmente a Câmara, prestar-lhe assessoria e consultoria jurídicas e exercer funções no âmbito do Poder Executivo. Por votação unânime, o Tribunal conheceu da ação e deferiu em parte o pedido de liminar para reduzir o âmbito da representação judicial da Câmara por sua Procuradoria-Geral aos casos em que aquele órgão do Poder Legislativo esteja em juízo em nome próprio; interditar-lhe o exercício de funções no âmbito do Executivo; e proibir-lhe a representação para efetuar a cobrança judicial das "dívidas para com a Câmara", como previa o inciso $\mathrm{V}$ do $\S 1^{\circ}$ do art. $1^{\mathrm{os} 3}$.

Por último, em outubro de 1997, a ANAPE propôs a Adin $n^{\circ} 1679$ contra a Emenda Constitucional $\mathrm{n}^{\circ} 17$ que, alterando o art. 118 da Constituição do Estado de Goiás, determinou a criação da "Procuradoria da Fazenda Estadual" para representar o citado Estado judicialmente na execução da dívida tributária, com quadro próprio, subordinado ao Secretário da Fazenda. O Tribunal, por maioria de votos, deferiu a liminar para determinar a suspensão dos efeitos da Emenda Constitucional atacada, em decisão que ainda não foi publicada ${ }^{54}$.

\section{Conclusão}

Toda exegese pressupõe um método. Para evitar ousadias teóricas nesse revolto campo de debates que é a hermenêutica constitucional, consideramos suficiente justificar a meta de, ante o problema enfrentado: a) ter encontrado um resultado constitucionalmente justo adotando procedimento racional e controlável; e, b) ter fundamentado esse resultado também de forma racional e controlável ${ }^{55}$. Essas foram as linhas hermenêuticas que guiaram a escolha dos argumentos propostos e a sua ordenação.

Do ponto de vista político-institucional, a Carta de 1988, longe de romper com as instituições vigorantes à época, em muitos tópicos, tratou apenas de renová-las, atualizá-las, quando não de repeti-las nos moldes preexistentes, tornando-as, contudo, compatíveis com a democratização do País e com as recentes conquistas sociais.

52 Op. cit., loc. cit.

53 DJU de 20.06.97.

54 A íntegra do voto do Relator, favorável ao deferimento da liminar, consta de: Informativo STF $n^{\circ}$ 90. Brasília. 5 de novembro de 1997.

55 CANotillo, J. J. Gomes. Direito Constitucional. 6a ed. Coimbra: Almedina. 1993. p. 209. 
A par da conservação, a Constituição de 1988 trouxe consigo muitas e importantes inovações. A tarefa renovadora do legislador, mesmo o constituinte, não se resume à identificação, no seio da sociedade, do máximo divisor comum ou das idéias que se tornaram consensuais ou amplamente majoritárias. Ao legislador, muitas vezes cabe a missão de fazer avançar os costumes sociais, a organização política, imitando o sucesso de modelos estrangeiros, e seguindo os passos do amadurecimento científico e filosófico, cujo conhecimento quase nunca está ao alcance do povo.

A inovação que representou o art. 132 da Constituição Federal guardou essas duas características: de um lado representou a institucionalização em nível federal de um modelo que já se tornara parte da organização dos Estados por obra dos legisladores locais; de outro, o constituinte avançou em relação aos costumes, ao dedicar aos Procuradores dos Estados a exclusividade no exercício da representação judicial e da consultoria jurídica dos Estados, garantindo-lhes as prerrogativas necessárias ao desempenho dessas funções, entre as quais, a de reunirem-se em órgão único.

Ao iniciarmos o presente estudo, justificamos a necessidade de interpretar o texto constitucional para revelar o princípio da unicidade orgânica das Procuradorias dos Estados. A necessidade de interpretar a Constituição decorre do fato de ser implícito o princípio citado. Fosse explícito, afastada estaria a atividade hermenêutica.

A essa altura, temos como demonstrada a existência da norma constitucional implícita que consagra o princípio da unicidade das Procuradorias. Não é demasiado acrescentar, no entanto, que o princípio da unicidade é implícito, no texto constitucional, não só em relação às Procuradorias estaduais, mas também relativamente a quase todos os órgãos referidos pela Constituição. Pode-se afirmar que, em regra, o princípio da unicidade orgânica é implícito no texto constitucional; só excepcionalmente o referido princípio é explícito, como, por exemplo, no inciso II do artigo $8^{\circ}$, que trata da unicidade sindical. Por isso, porque o princípio da unicidade prevalece mesmo sendo implícito, o fato de não constar explicitamente não sugere possa haver, por exemplo, mais de um Congresso Nacional (arts. 44 a 47, CF), mais de um Presidente da República (arts. 76 a 83, CF), mais de um Supremo Tribunal Federal (arts. 101 a 103, CF) etc.

E, como afirmado alhures, sediado o princípio da unicidade orgânica das Procuradorias dos Estados na Constituição Federal, compõe o estatuto básico da representação judicial e da consultoria jurídica dos Estados federados, valendo para todos eles, inclusive para o Estado de Minas Gerais.

Com tais razões, temos como demonstrada a inconstitucionalidade de quaisquer dispositivos de constituições estaduais ou legais que visem à divisão das atribuições exclusivas da carreira de Procurador do Estado, conferindo-as a outros órgãos, como ocorre, particularmente, no Estado de Minas Gerais.

\section{Bibliografia}

CANOTILHO, J. J. Gomes. Direito Constitucional. 6a ed. Coimbra: Almedina. 1993. 
CARDOSO, Cleia. O Controle Interno de Legalidade pelos Procuradores do Estado. in: Rev. de Informação Legislativa, $\mathrm{n}^{\circ} 118$, abr./jun. 1993. Brasília.

CASTRO FILHO, José O. de. Prática Forense, v. I. 2 ed. Rio de Janeiro: Forense, 1977.

CRETELLA JR., José. Comentários à Constituição de 1988.

DI PIETRO, Maria S. Z. Direito Administrativo. 5a ed. São Paulo: Atlas, 1995.

FAGUNDES, Miguel S. O Controle dos Atos Administrativos pelo Poder Judiciário. $3^{\mathrm{a}}$ ed. Rio de Janeiro: Forense, 1957.

FERREIRA, Pinto. Comentários à Constituição Brasileira, $5^{\circ}$ v. São Paulo: Saraiva. 1992.

FERREIRA, Sérgio A. Comentários à Constituição, v. 3. Rio de Janeiro: Freitas Bastos. 1991.

HORTA, Raul M. A Autonomia do Estado-Membro no Direito Constitucional Brasileiro. Belo Horizonte: Santa Maria. 1964.

BORGES, José A. A Experiência do Estado de Minas Gerais de uma Estrutura Partilhada da Representação do Estado em Juizo no XXIII Congresso de Procuradores de Estado,". Cf. XXIII Congresso de Procuradores de Estado - Teses. 1997.

LÔBO, Paulo L. N. Comentários ao Novo Estatuto da Advocacia e da OAB Brasília: Brasília Jurídica. 1994.

MAXIMILIANO, Carlos. Hermenêutica e Aplicação do Direito. 14a ed. Rio de Janeiro: Forense. 1994.

MEIRELLES, Hely Lopes. Direito Administrativo Brasileiro. $14^{\text {a }}$ ed. São Paulo: Revista dos Tribunais. 1989.

MOREIRA NETO, Diogo de F. As Funções Essenciais à Justiça e as Procuraturas Constitucionais. Revista da Procuradoria Geral do Estado de São Paulo, dez. 1991.

SESTA, Mário B. Advocacia de Estado: Posição Institucional. Rev. de Inf. Legislativa, $\mathrm{n}^{\circ} 117$, jan./mar. 1993. Brasília.

SILVA, José A. da. Curso de Direito Constitucional Positivo. $9^{\mathrm{a}}$ ed. São Paulo: Malheiros. 1994. 


\section{Questões de Concurso}

Paulo de Bessa Antunes

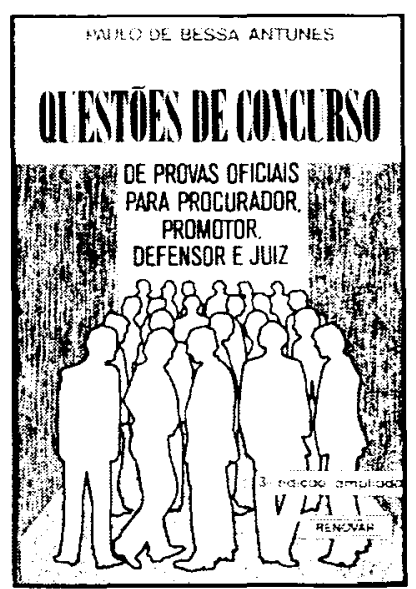

Aqui, o autor contribui com todos aqueles que desejam obter uma boa colocação nos diversos concursos públicos, além de ser uma excelente obra para o estudo do Direito em nível acadêmico. As questōes foram selecionadas em diversas provas de admissão, já realizadas pelas mais respeitáveis instituiçōes, tais como: Procuradoria-Geral da República, Tribunal Federal de Recursos, Procuradoria-Geral do Estado do Rio de Janeiro, Defensoria Pública do Rio de Janeiro.

Ref. 0009

Form. 14x21
Brochura

1992
296 págs.

$3^{\mathbf{a}}$ ed.

\section{Questões de Direito Imobiliário}

Silva Pacheco

Este livro contém os fundamentos do novo sistema de garantias reais imobiliárias do direito brasileiro, ressaltando a importância da fidúcia para os negócios modernos. Analisa a profunda reformulação que as garantias fiduciárias introduziram no direito imobiliário, em razāo da criação da alienação fiduciária de bens imóveis, da cessão fiduciária de direitos creditórios decorrentes da comercialização de imóveis e da caução de direitos aquisitivos sobre direitos imobiliários. $O$ autor expõe e comenta a Lei $n^{0} 9.514$, de 1997 .

Ref. 0196

Encadernado 608 págs.

Form. 16x23 1998

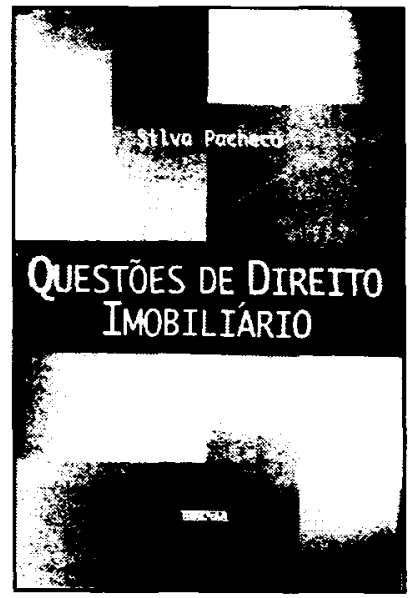

